\title{
HUBUNGAN FAKTOR LINGKUNGAN FISIK RUMAH DENGAN KEJADIAN PENYAKIT DEMAM BERDARAH DENGUE (DBD) DI WILAYAH PUSKESMAS CILACAP SELATAN II KABUPATEN CILACAP TAHUN 2016 Devi Farah Ghina'), Choiroel Anwar')
}

\author{
Jurusan Kesehatan Lingkungan, Politeknik Kesehatan Kemenkes Semarang, \\ Jl. Raya Baturaden KM 12 Purwokerto, Indonesia
}

\begin{abstract}
Abstrak
Penyakit Demam Berdarah Dengue yang selanjutnya disebut DBD adalah salah satu penyakit menular yang disebabkan oleh virus dengue dan ditularkan dari seorang penderita kepada orang lain melalui gigitan nyamuk Aedes aegypti. Tujuan penelitian untuk Mengetahui hubungan antara faktor lingkungan fisik rumah antara lain hubungan tempat penampungan air, keberadaan pakaian menggantung, suhu rumah, kelembaban rumah dan curah hujan dengan kejadian penyakit Demam Berdarah Dengue (DBD) di wilayah puskesmas Cilacap Selatan II Kabupaten Cilacap Tahun 2016. Jenis penelitian yang digunakan adalah studi analitik observasional desain studi case control. Sampel kasus adalah semua kasus penderita DBD di wilayah Puskesmas Cilacap Selatan II dari bulan Januari sampai bulan Mei 2016 (30 kasus). Sampel kontrol adalah tetangga yang tidak menderita DBD dengan kriteria jenis kelamin yang sama dan umur yang tidak jauh berbeda ( \pm 2 bulan) dengan penderita dengan jarak rumah radius $\pm 100 \mathrm{~m}$ (30 kontrol). Hasil penelitian dari 30 penderita, $20 \%$ terdapat TPA, 56,7 \% terdapat pakaian menggantung di dalam kamar rumah responden, 80 \% suhu memenuhi syarat, $100 \%$ kelembaban rumah memenuhi syarat. Tidak ada hubungan TPA dengan kejadian DBD, tetapi menjadi faktor risiko. Tidak ada hubungan keberadaan pakaian menggantung dengan kejadian DBD dan merupakan faktor risiko. Suhu rumah berhubungan tetapi nilai batas bawah kurang dari 1 dan dianggap tidak ada hubungan. Kelembaban rumah tidak berhubungan dengan kejadian DBD karena semua responden mendapatkan paparan yang sama (konstan). Curah hujan berhubungan dengan kejadian DBD dengan curah hujan tinggi meningkatkan jumlah kasus DBD. Kesimpulan penelitian ini adalah curah hujan berhubungan dengan kejadian DBD karena berpotensi menimbulkan banyak genangan air yang menjadi tempat perindukan nyamuk. Penelitian ini bersifat lemah karena sampel kontrol yang diambil tidak mampu menguatkan kasus.
\end{abstract}

Kata kunci : Lingkungan, Fisik, Rumah, DBD

\section{I.PENDAHULUAN}

Demam Berdarah Dengue merupakan salah satu penyakit yang masih menjadi masalah kesehatan masyarakat. Penyakit ini pertama kali dilaporkan pada tahun 1968 di Jakarta dan Surabaya, dengan 48 penderita dan angka kematian (CFR) sebesar 41,3\% . Hampir setiap tahun terjadi KLB (Kejadian Luar Biasa) dibeberapa daerah yang biasanya terjadi pada musim penghujan.

Kasus DBD tertinggi di Jawa Tengah pada tahun 2008 terjadi di 10 kota/kabupaten dengan kota Semarang tertinggi. Selain kota Semarang, daerah lain yang memiliki kasus tinggi adalah Kabupaten Kendal yaitu 479 kasus. Kabupaten Cilacap yang merupakan salah satu kabupaten di Jawa Tengah dengan data tiga tahun terakhir, didapatkan jumlah kasus pada tahun 2013 sebanyak 820 penderita dengan kasus meninggal 9 orang (CFR 1,09\%), tahun 2014 mencapai 447 penderita dengan kasus meninggal 6 orang (CFR 1,34\%) dan tahun 2015 sebanyak 983 penderita dengan kasus meninggal 10 orang (CFR 1,01\%).

Puskesmas Cilacap Selatan II berlokasi di Desa Tegalkamulyan. Puskesmas ini mencakup dua

1) Email : -

2) Email : choirul1960@gmail.com

Puskesmas Cilacap Selatan II merupakan daerah endemis penyebaran penyakit DBD. Kasus DBD di wilayah Puskesmas Cilacap Selatan II pada tahun 2013 sebanyak 37 kasus (IR =12,59), pada tahun
2014 mencapai 16 kasus (IR $=5,44)$ dan pada tahun 2015 sebanyak 59 kasus (IR =20,08). (Laporan Dinas Kesehatan Kabupaten Cilacap).

Faktor risiko yang berhubungan dengan penyakit DBD antara lain perilaku, suhu, kelembaban, curah hujan, ketinggian tempat, adanya tempat penampungan air dan tempat perindukan nyamuk.

Berdasarkan data Stasiun Meteorologi dan Geofisika Kabupaten Cilacap, banyaknya curah hujan tertinggi pada tahun 2013 terjadi pada bulan Juli $(507.0 \mathrm{~mm})$ dan terendah terjadi pada bulan September $(29 \mathrm{~mm})$. Suhu maksimum tertinggi tercatat $35,2^{\circ} \mathrm{C}$ terjadi pada bulan Maret dan suhu maksimum terendah $29,8^{\circ} \mathrm{C}$ terjadi pada bulan Agustus.

Sedangkan banyaknya curah hujan tertinggi pada tahun 2014 terjadi pada bulan Juli $(659.0 \mathrm{~mm})$ dan terendah terjadi pada bulan September $(4 \mathrm{~mm})$. Suhu maksimum tertinggi tercatat $34,4^{\circ} \mathrm{C}$ terjadi pada bulan April, dan suhu maksimum terendah $21,8^{\circ} \mathrm{C}$ terjadi pada bulan Agustus dan September. (Badan Pusat Statistik Kabupaten Cilacap).

Hasil pengamatan sementara peneliti di wilayah puskesmas Cilacap Selatan II kondisi lingkungan sekitar memang kurang saniter, hal tersebut dapat dilihat dengan adanya barang-barang bekas yang sudah tidak dipakai dalam keadaan terbuka dan berair, tentu saja ini akan menjadi tempat perindukan nyamuk penyebab DBD, selain itu adanya pakaian yang menggantung di kamar menjadikan nyamuk suka menghinggap. 
Tujuan penelitian ini adalah mengetahui hubungan antara faktor lingkungan fisik rumah antara lain hubungan tempat penampungan air, keberadaan pakaian menggantung, suhu rumah, kelembaban rumah dan curah hujan dengan kejadian penyakit Demam Berdarah Dengue (DBD) di wilayah puskesmas Cilacap Selatan II Kabupaten Cilacap Tahun 2016.

\section{II.BAHAN DAN METODE}

Jenis penelitian yang digunakan adalah studi analitik observasional desain studi case control untuk ukuran risiko (OR) dengan memilih kasus yang menderita DBD dengan kontrol yang tidak menderita DBD di wilayah Puskesmas Cilacap Selatan II Kabupaten Cilacap. Sampel kasus adalah semua kasus penderita DBD di wilayah Puskesmas Cilacap Selatan II dari bulan Januari sampai bulan Mei 2016 (30 kasus). Sampel kontrol adalah tetangga yang tidak menderita DBD dengan kriteria jenis kelamin yang sama dan umur yang tidak jauh berbeda $( \pm 2$ bulan) dengan penderita dengan jarak rumah radius \pm $100 \mathrm{~m}$ (30 kontrol).

Metode Pengumpulan Data yang dilakukan dengan wawancara dengan berdialog, Observasi dengan pengamatan dan pengukuran terhadap obyek penelitian untuk mendapatkan data mengenai Tempat penampungan Air (TPA), Suhu, Kelembaban dan Keberadaan pakaian menggantung.

\section{III.HASIL DAN PEMBAHASAN}

\section{Hasil}

UPT Puskesmas Cilacap Selatan II terletak di Jalan Lingkar Selatan No. 6 RT 05 RW 03 Kelurahan Tegalkamulyan Kecamatan Cilacap Selatan, terletak di tepi jalan besar yang mudah diakses oleh masyarakat. Jarak dari pusat pemerintahan kecamatan sekitar $1 \mathrm{~km}$ dan dari ibu kota kabupaten sekitar 2 $\mathrm{km}$.

Wilayah kerja UPT Puskesmas Cilacap Selatan II berupa dataran rendah yang dekat dengan pantai berbatasan dengan Samudra Hindia, dengan ketinggian $0-3 \mathrm{~m}$ di atas permukaan laut dan suhu udara rata-rata $30^{\circ} \mathrm{C}$.

Luas wilayah kerja UPT Puskesmas Cilacap Selatan II adalah sekitar $5.435 \mathrm{~km}^{2}$,yang terdiri dari 2 kelurahan : yaitu Kelurahan Cilacap dengan luas wilayah sekitar 123,6 Ha terdiri dari 18 RW dengan 97RT dan Kelurahan Tegalkamulyan dengan luas wilayah sekitar 293, 3 Ha terdiri dari 16 RW dengan 83 RT.

Berdasarkan data tahun 2015, diketahui bahwa wilayah kerja UPT Puskesmas Cilacap Selatan II mempunyai jumlah penduduk 37.041 jiwa dengan perincian Kelurahan Cilacap mempunyai jumlah penduduk 17.297 jiwa dengan 4.418 Kepala Keluarga terdiri dari 8.874 pria dan 8.423 wanita, dan Kelurahan Tegalkamulyan mempunyai jumlah penduduk 19.744 jiwa dengan jumlah kepala keluarga 4.013 terdiri dari 9.997 pria dan 9.747 wanita. Jumlah penduduk yang terbanyak adalah pada rentang umur 15 - 44 tahun sedangkan yang paling sedikit adalah pada umur dibawah 1 tahun.

Sedangkan dilihat dari segi pendidikanya sebagian besar berpendidikan SD/Sederajat yaitu sekitar 5.534 Orang dan selanjutnya adalah berpendidikan SMA/Sederajat yaitu sekitar 5.350 Orang.

Analasis Univariat

Tabel 1.5 Responden Menurut Umur di Wilayah Kerja Puskesmas Cilacap Selatan II Tahun 2016

\begin{tabular}{lccccc}
\hline \multirow{2}{*}{ No. Umur } & \multicolumn{2}{c}{ Kasus } & \multicolumn{2}{c}{ Kontrol } \\
\cline { 3 - 6 } & Responden & Jumlah & $\mathbf{\%}$ & Jumlah & \% \\
\hline 1. & $1-10$ th & 6 & $20 \%$ & 5 & $16,7 \%$ \\
2. & $11-20$ th & 6 & $20 \%$ & 6 & $20 \%$ \\
3. & $21-30$ th & 5 & $16,7 \%$ & 7 & $23,3 \%$ \\
4. & $31-40$ th & 6 & $20 \%$ & 6 & $20 \%$ \\
5. & $41-50$ th & 3 & $10 \%$ & 3 & $10 \%$ \\
6. & $51-60$ th & 3 & $10 \%$ & 1 & $3,3 \%$ \\
7. & $61-70$ th & 1 & $3,3 \%$ & 2 & $6,7 \%$ \\
\hline & Jumlah & 30 & $100 \%$ & 30 & $100 \%$ \\
\hline
\end{tabular}

Berdasarkan tabel di atas, karakteristik responden menurut umur dapat diketahui bahwa sampel kasus paling banyak pada rentang usia 1-10 tahun, 11-20 tahun dan 31-40 tahun dengan total prosentasi $60 \%$ sebanyak 18 orang dan kasus terendah pada rentang usia 61-70 tahun sebanyak 1 orang dengan prosentasi 3,3\%, sedangkan pada kontrol paling banyak usia 21-30 tahun dengan prosentasi 23,3 \% sebanyak 7 orang dan terendah usia 51-60 tahun sebanyak 1 orang dengan prosentasi $3,3 \%$.

Tabel 1.6 Responden Menurut Jenis Kelamin di Wilayah Kerja Puskesmas Cilacap Selatan II Tahun 2016

\begin{tabular}{clcccc}
\hline \multirow{2}{*}{ No. Jenis } & \multicolumn{2}{c}{ Kasus } & \multicolumn{2}{c}{ Kontrol } \\
\cline { 3 - 6 } & Kelamin & Jumlah & \% & Jumlah & \% \\
\hline 1. & Laki-laki & 15 & $50 \%$ & 15 & $50 \%$ \\
2. & Perempuan & 15 & $50 \%$ & 15 & $50 \%$ \\
\hline & Jumlah & 30 & $100 \%$ & 30 & $100 \%$ \\
\hline
\end{tabular}

Berdasarkan tabel di atas, karakteristik responden menurut jenis kelamin dapat diketahui bahwa sampel kasus dan kontrol dengan jenis kelamin laki-laki sebanyak 15 orang dan perempuan sebanyak 15 orang dengan prosentasi masing-masing $50 \%$.

Tabel 1.7 Responden Menurut Jenis Pekerjaan di Wilayah Kerja Puskesmas Cilacap Selatan II Tahun 2016

\begin{tabular}{llcccc}
\hline \multirow{2}{*}{ No. Jenis } & \multicolumn{2}{c}{ Kasus } & \multicolumn{2}{c}{ Kontrol } \\
\cline { 3 - 6 } & Pekerjaan & Jumlah & \% & Jumlah & $\%$ \\
\hline 1. & Buruh & 4 & $13,3 \%$ & 5 & $16,7 \%$ \\
2. & IRT & 10 & $33,3 \%$ & 13 & $43,3 \%$ \\
3. & Karyawan & 3 & $10 \%$ & 1 & $3,3 \%$
\end{tabular}




\begin{tabular}{llcccc} 
4. & Nelayan & 2 & $6,7 \%$ & 0 & $0 \%$ \\
5. & Pelajar & 11 & $36,7 \%$ & 11 & $36,7 \%$ \\
\hline & Jumlah & 30 & $100 \%$ & 30 & $100 \%$ \\
\hline
\end{tabular}

Berdasarkan tabel di atas, karakteristik
responden menurut jenis pekerjaan dapat diketahui bahwa sampel kasus paling banyak adalah pelajar sebanyak 11 orang dengan prosentasi 36,7\% dan terendah yaitu nelayan dengan prosentasi $67 \%$ sebanyak 2 orang, sedangkan pada kontrol paling banyak dengan jenis pekerjaanIbu Rumah Tangga dengan prosentasi 43,3\% sebanyak 13 orang dan tidak ditemukan sampel kontrol dengan pekerjaan nelayan.

Tabel 1.8 Responden Menurut Tingkat Pendidikan di Wilayah Kerja Puskesmas Cilacap Selatan II Tahun 2016

\begin{tabular}{|c|c|c|c|c|}
\hline \multirow[t]{2}{*}{ No. } & \multirow{2}{*}{$\begin{array}{c}\text { Tingkat } \\
\text { Pendidikan }\end{array}$} & Kasus & \multicolumn{2}{|c|}{ Kontrol } \\
\hline & & $\begin{array}{l}\text { Jumlah } \% \\
\end{array}$ & Jumlah & $\%$ \\
\hline 1. & $\begin{array}{l}\text { Menengah } \\
\text { Keatas }\end{array}$ & $17 \quad 56,7 \%$ & 17 & $56,7 \%$ \\
\hline 2. & $\begin{array}{l}\text { Pendidikan } \\
\text { Dasar }\end{array}$ & $43,3 \%$ & 13 & $43,3 \%$ \\
\hline & Jumlah & $100 \%$ & 30 & $100 \%$ \\
\hline & $\begin{array}{l}\text { Berdasarka } \\
\text { esponden men } \\
\text { ahwa sampe } \\
\text { endidikantertir } \\
\text { rosentasi 56,7 }\end{array}$ & $\begin{array}{l}\text { an tabel di } \\
\text { urut tingkat peno } \\
\text { el kasus da } \\
\text { nggi adalah me } \\
\% \text { sebanyak } 17\end{array}$ & $\begin{array}{l}\text { atas, } \\
\text { didikanda } \\
\text { n kont }\end{array}$ & $\begin{array}{l}\text { arakteristi } \\
\text { t diketahı } \\
\text { tingka } \\
\text { tas denga }\end{array}$ \\
\hline
\end{tabular}

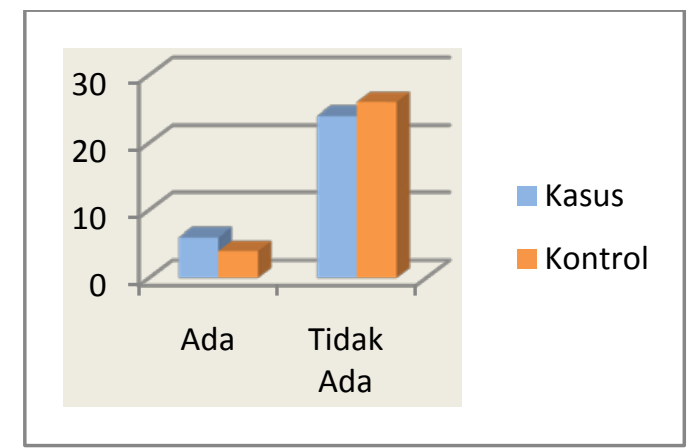

Gambar 2.5 Grafik TPA pada Kasus dan Kontrol

Berdasarkan grafik di atas, karakteristik responden menurut ada tidaknya tempat penampungan air di sekitar rumah dapat diketahui yaitu sampel kasus dan kontrol sebagian besar tidak terdapat TPA dengan prosentasi $80 \%$ dan 86,7 \%, pada sampel kasus sebanyak 6 responden terdapat TPA sedangkan kontrol dengan prosentasi 13,3\% sebanyak 4 orang.

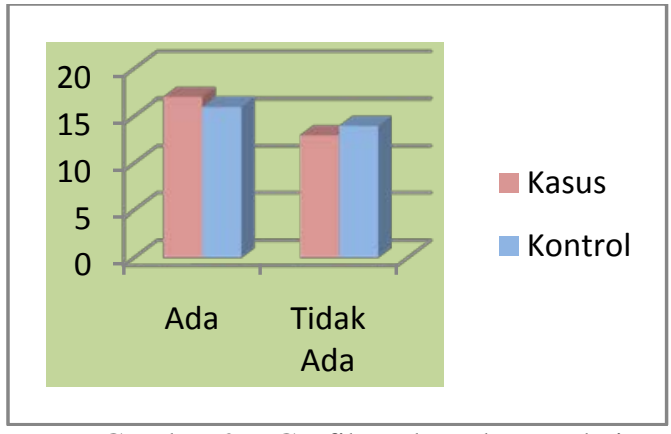

Gambar 2.6 Grafik Keberadaan Pakaian Menggantung pada Kasus dan Kontrol

Berdasarkan grafik di atas, karakteristik responden menurut ada tidaknya pakaian mengantung di dalam rumah dapat diketahui yaitu sebagian besar kasus dan kontrol terdapat pakaian menggantung di dalam rumah dengan sampel kasus sebanyak 17 orang dengan prosentasi 56,7 \% sedangkan pada kontrol dengan prosentasi 53,3 \% sebanyak 16 orang.

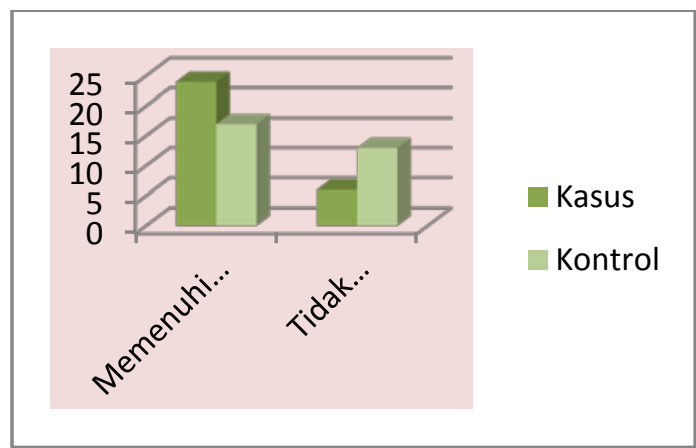

Gambar 2.7 Grafik Suhu pada Kasus dan Kontrol

Berdasarkan grafik di atas, karakteristik responden menurut hasil pengukuran suhu di dalam rumah, sampel kasus sebagian besar suhu memenuhi syarat sebanyak 24 orang dengan prosentasi $80 \%$, sedangkan sampel kontrol paling banyak 17 orang dengan prosentasi 56,7 \% memenuhi syarat.

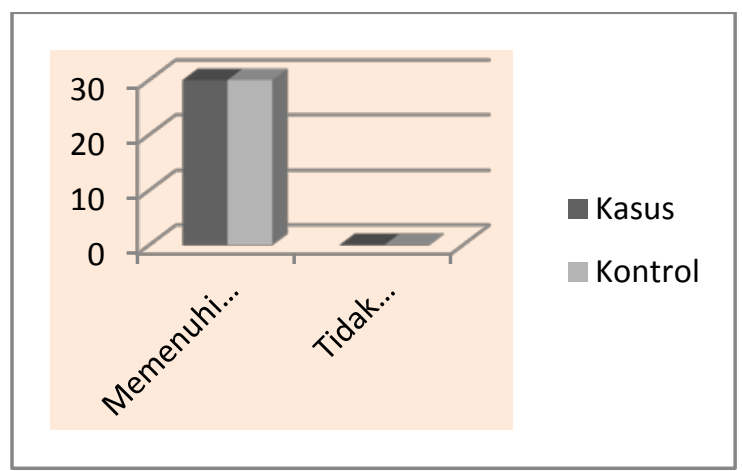

Gambar 2.8 Grafik Kelembaban Pada Kasus dan Kontrol

Berdasarkan grafik di atas, karakteristik responden menurut hasil pengukuran kelembaban di dalam rumah yang memenuhi syarat dan tidak memenuhi syarat, sampel kasus dan kontrol seluruhnya memenuhi syarat sebanyak 30 dengan prosentasi $100 \%$. 


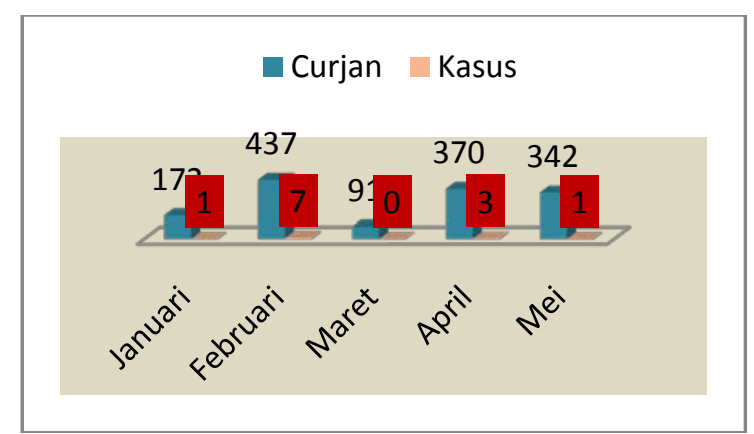

Gambar 2.9 Grafik Curah Hujan Rata-rata Bulanan dan Jumlah Kasus DBD

(Sumber : Badan Meteorologi Klimatologi dan Geofisika)

Berdasarkan grafik di atas, curah hujan di wilayah kecamatan Cilacap Selatan dari mulai bulan Januari sampai Mei Tahun 2016 tertinggi pada bulan Februari yaitu $437 \mathrm{~mm}$, sedangkan terendah pada bulan Maret yaitu $91 \mathrm{~mm}$. Sedangkan kasus DBD tertinggi pada bulan Februari sebanyak 7 kasus dan terendah pada bulan Maret.

\section{Analisis Bivariat}

1. Hubungan tempat penampungan air dengan kejadian penyakit Demam Berdarah Dengue (DBD) di wilayah puskesmas Cilacap Selatan II

Hasil uji statistik Chi Square (selengkapnya dapat dilihat dilampiran), dengan nilai signifikansi sebesar 5\% $(0,05)$ dan df sebesar 1 , diperoleh nilai $X^{2}$ hitung sebesar 0,120 sedangkan nilai $X^{2}$ tabel sebesar 3, 481. Dengan demikian nilai p-value yaitu 0,729 lebih besar dari alpha 5\% $(0,05)$ sehingga Ha ditolak, berarti tidak ada hubungan antara tempat penampungan air dengan kejadian DBD.

Hasil uji statistik Odd Ratio (OR) senilai 1,625 (CI=0,408-6,469).

2. Hubungan keberadaan pakaian menggantung dengan kejadian penyakit Demam Berdarah Dengue (DBD) di wilayah puskesmas Cilacap Selatan II

Hasil uji statistik Chi Square (selengkapnya dapat dilihat dilampiran), dengan nilai signifikansi sebesar $5 \%(0,05)$ dan df sebesar 1 , diperoleh nilai $\mathrm{X}^{2}$ hitung sebesar 0,625 sedangkan nilai $\mathrm{X}^{2}$ tabel sebesar 3 , 481. Dengan demikian nilai $\mathrm{p}$-value yaitu 0,429 lebih besar dari alpha 5\% $(0,05)$ sehingga Ha ditolak, berarti tidak ada hubungan antara keberadaan pakaian menggantung dengan kejadian DBD.

Hasil uji statistik Odd Ratio (OR) senilai $1,625(\mathrm{CI}=0,616-4,973)$.

3. Hubungan suhu dengan kejadian penyakit Demam Berdarah Dengue (DBD) di wilayah puskesmas Cilacap Selatan II

Hasil uji statistik Chi Square (selengkapnya dapat dilihat dilampiran), dengan nilai signifikansi sebesar $5 \%(0,05)$ dan df sebesar 1 , diperoleh nilai $X^{2}$ hitung sebesar 2,773 sedangkan nilai $\mathrm{X}^{2}$ tabel sebesar 3, 481. Dengan demikian nilai p-value yaitu 0,96 lebih besar dari alpha 5\% $(0,05)$ sehingga Ha ditolak, berarti tidak ada hubungan antara suhu dengan kejadian DBD.

Hasil uji statistik Odd Ratio (OR) senilai 0,327 (CI=0,014-1,032)

4. Hubungan kelembaban dengan kejadian penyakit Demam Berdarah Dengue (DBD) di wilayah puskesmas Cilacap Selatan II

Hasil uji statistik Chi Square dan hasil Odd Ratio (OR), kelembaban rumah tidak dapat dianalisis karena kelembaban antara rumah kasus dan kontrol mempunyai paparan yang sama atau bersifat konstan (tetap). Sehingga kelembaban rumah tidak berhubungan dengan kejadian penyakit DBD.

5. Hubungan curah hujan dengan kejadian penyakit Demam Berdarah Dengue (DBD) di wilayah puskesmas Cilacap Selatan II

kasus DBD tertinggi pada bulan Februari sebanyak 7 kasus dan curah hujan tertinggi pada buan Februari yaitu 437mm, sedangkan curah hujan terendah pada bulan Maret yaitu $91 \mathrm{~mm}$ dan tidak terdapat kasus DBD.

\section{Pembahasan}

Wilayah kerja Puskesmas Cilacap Selatan II beriklim tropis karena dekat dengan pantai berbatasan dengan Samudra Hindia dengan ketinggian $3 \mathrm{~m}$ di atas permukaan laut dan suhu udara rata-rata $30^{\circ} \mathrm{C}$, kelembaban udara rata-rata berkisar antara. Pada musim hujan akan menambah genangan air sebagai tempat perindukan nyamuk sekaligus menambah kelembaban udara. Temperatur dan kelembaban selama musim hujan sangat kondusif untuk kelangsungan hidup nyamuk, karena tingkat kelembaban optimum nyamuk adalah 60-80 \% dan suhu optimum pertumbuhan nyamuk adalah 26-32 ${ }^{\circ} \mathrm{C}$, sehingga menyebabkan banyak terjadi berbagai penyakit menular seperti penyakit Demam Berdarah Dengue (DBD).

1. Responden Menurut Umur

Berdasarkan tabel 1.5 jumlah kasus Demam Berdarah Denguebanyak menyerang penderita dengan rentang usia 1-10 tahun, 11-20 tahun dan 31-40 tahun sebanyak 18 orang dengan prosentasi $60 \%$ sedangkan pada kontrol kasus banyak menyerang usia 21-30 tahun dengan prosentasi 23,3 \% sebanyak 7 orang. Kecenderungan meningkatnya penderita DBD sekarang tidak pandang usia, dari mulai usia anak, remaja dan dewasa dapat terserang DBD, hal tersebut dikarenakan banyaknya aktivitas di luar rumah yang memudahkan penularan penyakit.

2. Responden Menurut Jenis Kelamin

Berdasarkan tabel 1.6 jumlah kasus Demam Berdarah Dengue menyerang penderita kasus dan kontrol dengan jenis kelamin laki-laki dan perempuan yang sama yaitu sebanyak 15 orang 
dengan total 30 orang. Dalam hal ini, kasus DBD tidak pandang jenis kelamin karena laki-laki dan perempuan mempunyai potensi yang dapat tertular penyakit DBD dari orang/penderita lain .

3. Responden Menurut Jenis Pekerjaan

Berdasarkan tabel 1.7 jumlah kasus Demam Berdarah Dengue banyak menyerang penderita pelajar sebanyak 11 orang dengan prosentasi 36,7 \% sedangkan pada kontrol IRT (Ibu Rumah Tangga) sebanyak 13 orang dengan prosentasi 43,3 \%. Jenis pekerjaan yang banyak menyerang pada pelajar yang kegiatannya banyak di sekolah dibandingkan di rumah dan mempunyai perkumpulan bersama orang lain yang dapat memudahkan penularan penyakit DBD. Selain itu, ibu rumah tangga yang aktivitasnya lebih banyak di rumah dan tidur pada siang hari mempunyai risiko tertular penyakit DBD.

4. Responden Menurut Tingkat Pendidikan

Berdasarkan tabel 1.8jumlah kasus Demam Berdarah Dengue banyak menyerang penderita dengan tingkat pendidikan menengah ke atas (SMP, SMA dan Perguruan Tinggi) sebanyak 17 orang dengan prosentasi 56,7\%. Pendidikan yang baik juga dapat memberikan pengetahuan yang cukup terhadap segala sesuatu, misalnya tentang penyakit DBD. Tingkat pendidikan juga akan mempengaruhi cara berfikir dalam penerimaan penyuluhan dan cara pemberantasan yang dilakukan.

5. Tempat Penampungan Air (TPA)

Berdasarkan grafik 2.5menurut ada atau tidak adanya tempat penampungan air di sekitar rumah, pada kasus sebanyak 6 terdapat TPA dengan prosentasi $20 \%$ sedangkan kontrol sebanyak 4 responden terdapat TPA dengan prosentasi 13,3 \%. Nyamuk berkembang biak di tempat tempat yang yang bersih seperti tempayan, bak mandi, botol-botol bekas, ban bekas dan potongan bambu yang tidak menyentuh tanah. Jika tempat penampungan air jarang dibersihkan memungkinkan menjadi tempat perindukan nyamuk.

6. Keberadaan Pakaian Menggantung

Berdasarkan grafik 2.6 menurut ada atau tidak adanya pakaian menggantung di dalam rumah, sebagian besar terdapat pakaian menggantung. Pada kasus 17 rumah dengan prosentasi 56,7 \% terdapat pakaian menggantung di dalam kamar dan pada kontrol sebanyak 16 rumah dengan prosentasi 53,3 \% terdapat pakaian menggantung. Dengan adanya pakaian menggantung di dalam kamar menjadikan nyamuk berada di dalam kamar dan menambah populasi nyamuk karena nyamuk suka beristirahat pada pakaian kotor yang berwarna gelap setelah kebiasaannya menggigit darah.

7. Suhu

Berdasarkan grafik 2.7suhu rumah yang memenuhi syarat $\left(26-32^{\circ} \mathrm{C}\right)$ dan tidak memenuhi syarat $\left(<26^{\circ} \mathrm{C}\right.$ dan $\left.>32^{\circ} \mathrm{C}\right)$ sebagian besar rumah responden suhu rumahnya memenuhi syarat. Pada kasus sebanyak 24 rumah yang suhunya memenuhi syarat dengan prosentasi 80 \% sedangkan pada kontrol 17 rumah dengan prosentasi 56,7 \% suhunya memenuhi syarat. Suhu optimum perkembang biakan nyamuk di dalam rumah yaitu berkisar antar $26-32^{\circ} \mathrm{C}$. Dalam rentang suhu tersebut, nyamuk akan lebih lama hidup dan berkembang biak selama beberapa hari.

8. Kelembaban

Berdasarkan grafik 2.8kelembaban rumah yang memenuhi syarat (60-80 \%) dan tidak memenuhi syarat $(<60 \%$ dan $>80 \%)$. seluruh rumah pada kasus dan kontrol kelembaban rumahnya memenuhi syarat. Dari total jumlah 60 rumah kelembaban rumah memenuhi syarat semua. Kelembaban optimum pertumbuhan nyamuk yaitu 60-80 \%. Dengan keadaan kelembaban yang optimal umur nyamuk dapatmencapai lebih dari 1(satu) bulan. Secara tidak langsung kelembaban dapat berpengaruh terhadap umur nyamuk dalam kesempatannya untuk menjadi vektor.

9. Curah Hujan

Berdasarkan tabel 2.9curah hujan bulanan di wilayah kecamatan Cilacap Selatan tertinggi pada bulan Februari yaitu $437 \mathrm{~mm}$ dengan jumlah kasus sebanyak 7. Sedangkan curah hujan terendah terjadi pada bulan Maret yaitu $91 \mathrm{~mm}$ dan tidak ditemukan kasus. Curah hujan dapat mempengaruhi pola makan dan reproduksi nyamuk sertameningkatkan kepadatan populasi nyamuk. Fakor curah hujan berhubungandengan evaporasi dan suhu mikro di dalam kontainer (sarang nyamuk di luar rumah).Dengan demikian populasi nyamuk meningkat drastis pada awal musim hujan.

\section{Analisis Bivariat}

1. Hubungan tempat penampungan air dengan kejadian penyakit Demam Berdarah Dengue (DBD)

Berdasarkan hasil Uji Statistik Chi Square dengan nilai signifikansi sebesar $5 \%(0,05)$ dan df sebesar 1 , diperoleh nilai $\mathrm{X}^{2}$ hitung sebesar 0,120 sedangkan nilai $X^{2}$ tabel sebesar 3,481 . Dengan demikian nilai p-value yaitu 0,729 lebih besar dari alpha $5 \%(0,05)$ sehingga Ha ditolak, berarti tidak ada hubungan antara tempat penampungan air dengan kejadian DBD.

Hasil perhitungan Odd Ratio diperoleh hasil senilai $1,625(\mathrm{CI}=0,408-6,469)$, walaupun nilai OR lebih dari 1 tetapi batas bawah CI kurang dari 1 sehingga tidak berhubungan.Berdasarkan penelitian Erna menyatakan adanya hubungan tempat penampungan air dengan kejadian penyakit DBD. Tempat penampungan air erat kaitannya dengan tempat perindukan nyamuk 
Aedes aegypti seperti bak mandi, drum, ban bekas, potongan bambu dan wadah bekas yang terbuka dan berair lainnya. Jumlah wadah terbuka serta frekuensi pembersihan dapat memberi peluang pada nyamuk dewasa untuk meletakkan telurnya sampai menetas sampai menjadi nyamuk dewasa. Hal ini berbanding terbalik dengan penelitian yang peneliti lakukan, disebabkan karena besarnya prosentasi tidak ditemukan TPA pada kasus $80 \%$ dan pada kontrol 86,7 \%. Selain itu, hanya ditemukan jentik nyamuk pada 1 rumah responden kasus dari 30 responden kasus. Sebgaian besar responden kasus tidak ditemukan jentik karena kemungkinan pelaksanaan PSN yang teratur sehingga tidak banyak ditemukan jentik (hasilnya negatif).

2. Hubungan keberadaan pakaian menggantung dengan kejadian penyakit Demam Berdarah Dengue (DBD)

Berdasarkan hasil Uji Statistik Chi Square dengan nilai signifikansi sebesar $5 \%(0,05)$ dan df sebesar 1 , diperoleh nilai $\mathrm{X}^{2}$ hitung sebesar 0,625 sedangkan nilai $\mathrm{X}^{2}$ tabel sebesar 3,481 . Dengan demikian nilai p-value yaitu 0,429 lebih besar dari alpha $5 \%(0,05)$ sehingga Ha ditolak, berarti tidak ada hubungan antara keberadaan pakaian menggantung dengan kejadian DBD. Hasil perhitungan Odd Ratio diperoleh hasil senilai 1,625 (CI=0,616 - 4,973) walaupun nilai OR lebih dari 1 tetapi batas bawah CI kurang dari 1 sehingga tidak berhubungan.

Berdasarkan penelitian Suyasa menyatakan adanya hubungan positif antara kebiasaan menggantung pakaian dengan keberadaan vektor DBDArman, 2005). Ae. Aegypti beristirahat pada pakaian yang tergantung di kamar yang telah dipakai, karena pada pakaian terdapat beberapa zat yang dapat menarik nyamuk seperti asam amino, asam laktat dan zat-zat lainnya. Nyamuk tertarik pada aroma tubuh manusia karena karbondioksida dari pernafasan.Selanjutnya jika pakaian tersebut digantung maka akan meningkatkan populasi nyamuk yang hidup di dalam rumah.Hal tersebut berlawanan dengan penelitian yang peneliti lakukan, karena prosentasi jumlah pakaian menggantung pada sampel kasus dan kontrol memiliki perbandingan yang sedikit.

3. Hubungan suhu dengan kejadian penyakit Demam Berdarah Dengue (DBD)

Berdasarkan hasil Uji Statistik Chi Square dengan nilai signifikansi sebesar $5 \%(0,05)$ dan df sebesar 1 , diperoleh nilai $\mathrm{X}^{2}$ hitung sebesar 2,773 sedangkan nilai $X^{2}$ tabel sebesar 3,481 . Dengan demikian nilai p-value yaitu 0,96 lebih besar dari alpha $5 \%(0,05)$ sehingga Ha ditolak, berarti tidak ada hubungan antara suhu dengan kejadian DBD.
Hasil perhitungan Odd Ratio diperoleh hasil senilai $0,327 \quad(\mathrm{CI}=0,104-1,032)$ nilai batas bawah CI kurang dari 1 sehingga tidak berhubungan.

Suhu mempengaruhi menetasnya larva Aedes aegypti menjadi pupa dandewasa. "Suhu yang terbaik menetaskan larva menjadi dewasa antara suhu $26^{\circ} \mathrm{C}-32^{\circ} \mathrm{C}$, bila suhu terlalu ekstrim dibawah $26^{\circ} \mathrm{C}$ atau di atas $32^{\circ} \mathrm{C}$ maka dayapenetasan larva menjadi dewasa akan menurun. Walaupun pada suhu $10^{\circ} \mathrm{ClarvaAedes}$ aegypti akan menetas tapi tidak begitu sempurna” (Clement, 1992dalam Cahyati (2006). Hal ini berbanding terbalik dengan penelitian yang peneliti lakukan disebabkan karena, prosentasi suhu rumah pada sampel kasus dan kontrol memiliki perbedaan yang sedikit.

4. Hubungan kelembaban dengan kejadian penyakit Demam Berdarah Dengue (DBD)

Berdasarkan hasil Uji Statistik Chi Square dan perhitungan Odd Ratio, kelembaban rumah tidak dapat dianalisis karena kelembaban antara rumah kasus dan kontrol mempunyai paparan yang sama atau bersifat konstan (tetap). Sehingga kelembaban rumah tidak berhubungan dengan kejadian penyakit DBD.

5. Hubungan curah hujan dengan kejadian penyakit Demam Berdarah Dengue (DBD)

Berdasarkan grafik 2.10menunjukkan kasus DBD tertinggi pada bulan Februari sebanyak 7 kasus dan curah hujan tertinggi pada buan Februari yaitu $437 \mathrm{~mm}$, sedangkan curah hujan terendah pada bulan Maret yaitu $91 \mathrm{~mm}$ dan tidak terdapat kasus DBD.

Curah hujan yang tinggi sangat mempengaruhi terjadinya penyakit DBD, karena pada curah hujan yang tinggi memungkinkan banyak terjadinya genangan air yang dapat menjadi tempat perindukan nyamuk DBD. Selain itu, dapat mempengaruhi pola makan dan reproduksi nyamuk sertameningkatkan kepadatan populasi nyamuk. Faktor curah hujan berhubungandengan evaporasi dan suhu mikro di dalam kontainer (sarang nyamuk di luar rumah).Dengan demikian populasi nyamuk meningkat drastis pada awal musim hujan yangdiikuti oleh meningkatnya kasus DBD di daerah tersebut. Terbukti pada bulan Februari dengan curah hujan tertinggi yaitu $437 \mathrm{~mm}$ diikuti dengan jumlah kasus DBD yang tinggi sebanyak 7 kasus.

\section{UCAPAN TERIMA KASIH}

Terima kasih disampaikan kepada Direktur Politeknik Kesehatan Kemenkes Semarang, Ketua Jurusan Kesehatan Lingkungan Purwokerto, Ketua Program Studi Diploma III Kesehatan Lingkungan Purwokerto, Pembimbing Akademik, Pembimbing Karya Tulis, dan semua pihak yang membantu pelaksanaan penelitian. 


\section{DAFTAR PUSTAKA}

Aris Santjaka, 2011, Statistik Untuk Penelitian Kesehatan 1, Yogyakarta : Nuha Medika

Badan Meteorologi dan Geofisika Kabupaten Cilacap, 2014, Data Iklim Kabupaten Cilacap, Cilacap : Badan Meteorologi dan Geofisika Kabupaten Cilacap

Badan Pusat Statistik Kabupaten Cilacap, 2014, Kabupaten Cilacap Dalam Angka Tahun 2014, Cilacap: Badan Pusat Statistik Kabupaten Cilacap

Badan Pusat Statistik Kabupaten Cilacap, 2015, Kabupaten Cilacap Dalam Angka Tahun 2015, Cilacap: Badan Pusat Statistik Kabupaten Cilacap

Badan Pusat Statistik Kabupaten Cilacap, 2014, Kecamatan Cilacap Selatan Dalam Angka Tahun 2014, Cilacap: Badan Pusat Statistik Kabupaten Cilacap

Buletin Jendela Epidemiologi, 2010, “Demam Berdarah Dengue”, Jakarta : Pusat Data dan Survailans Epidemiologi Kementerian Kesehatan RI Vol.2

Cecep Dani Sucipto, 2011, Vektor Penyakit Tropis, Yogyakarta: Gosyen Publishing

Dinas Kesehatan Kabupaten Cilacap, 2015, Laporan Kasus Demam Berdarah Dengue Tahun 2015, Cilacap: Dinas Kesehatan Kabupaten Cilacap
Dirjen PP \& PLP, 1992, Petunjuk Teknis Pemberantasan Nyamuk Penular Penyakit Demam Berdarah Dengue, Jakarta: Depkes RI

Fauzan Ma'ruf, 2011, Hubungan Lingkungan Dengan Kejadian Penyakit Demam Berdarah Dengue (DBD) di Kabupaten Banyumas tahun 2011, Purwokerto : Kemenkes RI Politeknik Kesehatan Semarang Jurusan Kesehatan Lingkungan Purwokerto

Irna Uswatul Hasanah, 2012, Faktor-Faktor Lingkungan Fisik Rumah yang berhubungan dengan kejadian penyakit Demam Berdarah Dengue (DBD) di wilayah Puskesmas Banjarnegara I Kabupaten Banjarnegara Tahun 2012, Purwokerto : Kemenkes RI Politeknik Kesehatan Semarang Jurusan Kesehatan Lingkungan Purwokerto

Lintje Boekoesoe, 2013, Kajian Faktor Lingkungan terhadap Kasus Demam Berdarah Dengue (DBD) Studi Kasus di Kota Gorontalo Provinsi Gorontalo Tahun 2013, Gorontalo : Universitas Negeri Gorontalo

Puskesmas Cilacap Selatan II, 2015, Laporan kasus Demam Berdarah Dengue di wilayah Puskesmas Cilacap Selatan II, Cilacap: Puskesmas Ciacap Selatan II

Tri Cahyono, 2014, Pedoman Penulisan Proposal Penelitian Ilmiah/Skripsi (Edisi Revisi Ke Tiga), Purwokerto : Jurusan Kesehatan Lingkungan Purwokerto, 